\title{
Walloon Language
}

National Cancer Institute

\section{Source}

National Cancer Institute. Walloon Language. NCI Thesaurus. Code C154197.

A Romance language that is spoken in the Wallonia region in Belgium and some villages

of Northern France. 